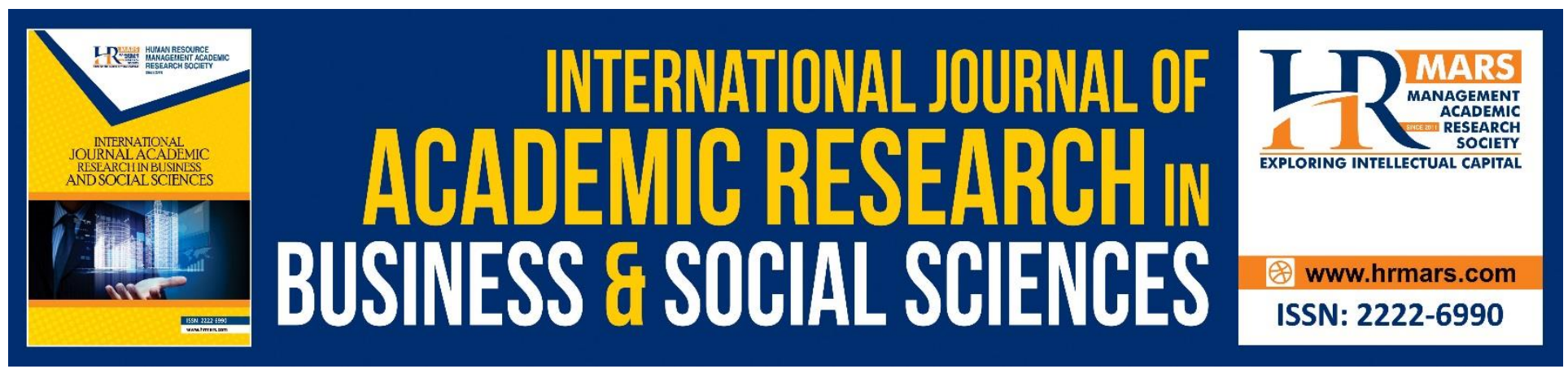

\title{
Establishing a Strategy for Developing Agricultural Pensions in Romania
}

Octavian Arsene, Diana Dumitru, Ana Maria Radu

To Link this Article: http://dx.doi.org/10.6007/IJARBSS/v9-i5/5837

DOI: $10.6007 /$ IJARBSS/v9-i5/5837

Received: 23 March 2019, Revised: 17 April 2019, Accepted: 16 May 2019

Published Online: 30 May 2019

In-Text Citation: (Arsene, Dumitru, \& Radu, 2019)

To Cite this Article: Arsene, O., Dumitru, D., \& Radu, A. M. (2019). Establishing a Strategy for Developing Agricultural Pensions in Romania. International Journal of Academic Research Business and Social Sciences, 9(5), 1-21.

Copyright: (C) 2019 The Author(s)

Published by Human Resource Management Academic Research Society (www.hrmars.com)

This article is published under the Creative Commons Attribution (CC BY 4.0) license. Anyone may reproduce, distribute, translate and create derivative works of this article (for both commercial and non-commercial purposes), subject to full attribution to the original publication and authors. The full terms of this license may be seen

at: http://creativecommons.org/licences/by/4.0/legalcode

\section{Vol. 9, No. 5, 2019, Pg. 1 - 21}

Full Terms \& Conditions of access and use can be found at http://hrmars.com/index.php/pages/detail/publication-ethics 


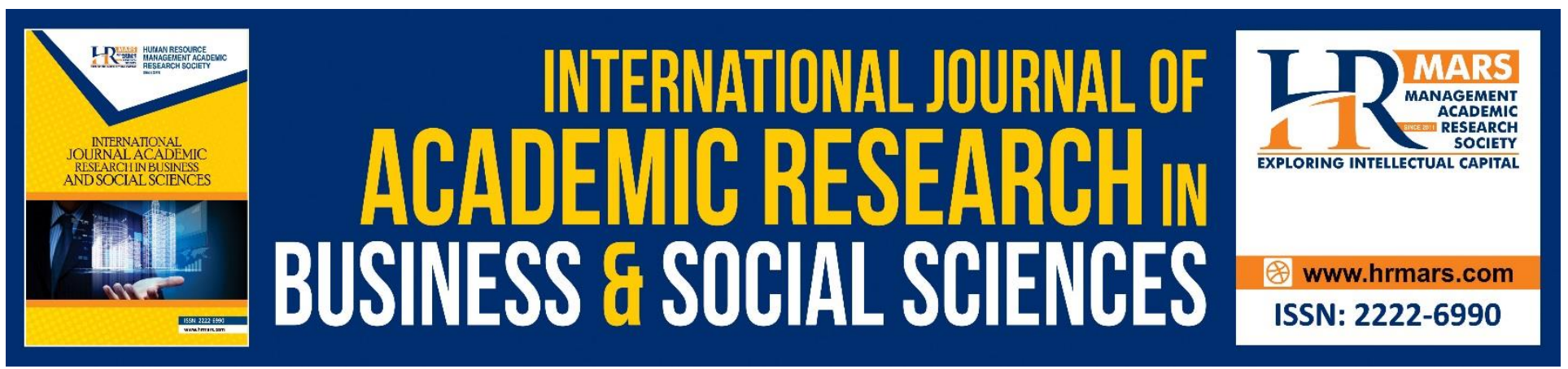

\title{
Establishing a Strategy for Developing Agricultural Pensions in Romania
}

\author{
Octavian Arsene ${ }^{1}$, Diana Dumitru², Ana Maria Radu ${ }^{3}$ \\ The Bucharest University of Economic Studies, Bucharest, Romania
}

\begin{abstract}
As rural tourism gains more and more popularity, it is important to establish a series of possible guidelines and suggestions on developing this tourism area especially when it comes to rural boarding houses. Moreover, the mountain area development can be used for encountering sustainable development through proper regulation, collaboration between authorities and population and financial support. The paper aims to present several solutions and suggests some guidelines on how the existing situation of the agricultural boarding houses in Romania, could be improved. The analysis is conducted on Romania, using existing data related to 2018 year's end, being a qualitative analysis based on several recommendations suggested by the authors that can be done to improve the development of mountain area. The strategy proposed, emphasizes the fact that in order to obtain reliable results collaboration between the authorities and the owners of the boarding houses have to be implemented, both on short, medium and long term.
\end{abstract}

Keywords: Rural tourism, agricultural boarding house, rural development, mountain area

\section{Introduction}

The problem of sustainable mountain area is not new as it was first taken into consideration in 1992 , in Chapter 13 of the Agenda 21 (Price and Kim, 1999). In 2002, the year was considered to be "the international year of mountains" so several development strategies were implemented or proposed, both at national and at international level. Moreover, the accession of Romania in the European Union also implies that some regulation and measures were implemented. Among them, we emphasize both the role of "Romania's Sustainable Development Strategy 2007-2030" and the "National Tourism Master Plan, 2007-2026".

The paper focuses on the tourism component of the mountain area that is in close connection with the areas where there are agro-touristic boarding houses $(A B H)$. Thus, the study proposes, on the

\footnotetext{
${ }^{1}$ octavianarsene2015@gmail.com

2 diaa1dumitru@yahoo.com
} 
basis of an analysis of the existing situation, to identify a series of measures, actions, directions and guidelines that should underpin a future strategy for the development of this form of accommodation at a higher level in the disadvantaged mountain area (DMA). The paper does not aim to create a strategy for the development of rural guest houses or to carry out detailed analyzes (SWOT type, for example) or to identify the objectives that should be taken on regional and national level, but only to form the basis of such a future analysis. The research is structure as follows: first part presents some aspects regarding the literature review and the regulation from Romania, the second part looks at the methodology of research, the third part presents the results or in other words, the recommendations proposed by the authors. The paper ends with a short section of conclusion.

\section{Literature Review}

The "Sustainable Development Strategy of Romania, 2013-2020-2030 Horizons (Romanian Government, 2008)" established several objected related to the inclusion of vulnerable groups, increase of life quality, consolidation of environmental business, both at regional and local level, improvement of the regional and local infrastructure. Among them, we found tourism objectives such as sustainable development and promotion of tourism activities, such as:

- Creating, developing and upgrading the specific infrastructure that produces sustainable value added of natural resources and that increase the quality of services that belong to tourism area. Regarding the potential of mountain tourism area, the strategy aims to improve the access routes to mountain camping and alpine retreats, to install mountain rescue posts, to develop the mountain - spa tourism, to create, increase and expand the accommodation and leisure facilities as well as their utilities that belong to tourism area

- Promoting the tourism potential and creating the necessary infrastructure that increase the attractiveness of Romania as a tourist destination by defining and promoting the national tourist brand, by developing the domestic tourism through the diversification of the supply and the implementation of specific market activities.

These main objectives aim to increase the attractiveness of tourism area and the development of local communities, through constructions, transport, natural and cultural heritage.

The "National Tourism Master Plan, 2007-2026" was conducted together with the support of World Tourism Organization and has several objectives, among which are increasing and encouraging the investment in all related sector areas of tourism, strengthening the enhancement and the preservation of cultural heritage and the distribution of the benefits of tourism services in all Romania' regions.

We also have to emphasize what the "National Strategy for suatinable development of Romania, 2030" aims to achieve. Among the 2030 targets there are the increasing of the quality of life of the population, achieving a competitive tourism activity in the long run and developing the agro-tourism, eco-tourism, rural tourism, spa and cultural tourism by improving the image that Romania has as a touristic destination. Other target that has to be completed is related with the creating value added of specific cultural resources that belong to rural or local area by protecting the cultural heritage, identifying the cultural activities and the traditional occupations such as: artisanal, artistic, culinary, and by encouraging further development of agro-tourism area. 


\section{Methodology of Research}

The paper focuses on the tourism component of the mountain area that is in close connection with the areas where there are agro-touristic boarding houses $(\mathrm{ABH})$ and tries to identify a series of measures, actions, directions and guidelines that should underpin a future strategy for the development of this form of accommodation at a higher level in the disadvantaged mountain area (DMA).

The authors started considering that the $A B H$ is not regarded as an isolated entity, but closely related to the destination where it was built. By default, some of the proposed measures refer not only to the $\mathrm{ABH}$ 's themselves, but also to the tourist destination where it is built. It is natural, therefore, that these measures aim to integrate the tourist offer of the destination.

The paper is based on an audit focusing exclusively on agro-touristic boarding houses $(\mathrm{ABH})$, respectively the tourism potential of the destination where it was built. Any possible further development of the paper should make a complete analysis / audit of the destinations, from all points of view. The potential is assessed in accordance with the relevant Romanian legislation, namely the National Territorial Planning Plan.

Although the Romanian rural tourism potential is exceptional, the effects of its practice do not amount to the existing natural resources, which is why Romania is at a considerable distance from the international competitors. (Stancioiu, 2004)

The research started exclusively from the existing situation of the $\mathrm{ABH}^{\prime} \mathrm{s}$ by the time of 01.02.2018 in the Ministry of Tourism database, with classified accommodation structures

(www.turism.gov.ro/01.02.2018).

To conduct the analysis, we used a number of criteria that are based on the legislation:

a) Areas that are included exclusively in the Disadvantaged Mountain Area (DMA) have been investigated;

b) From the counties included in the Disadvantaged Mountain Area, we chose only the territorial administrative units that are part of the DMA;

c) The third criteria used was related to the tourist heritage of the counties of DMA, of the territorial administrative units (t.a.u.). Those a.u. which have great touristic potential.

In order to accomplish this study, specialized papers in the field of tourism and regional development have been consulted (Studii OMT: “Organizația Mondială a Turismului - Rural Tourism, A solution for Employment, Local Development and Environment, 1997" ), courses from the data base of the specialized universities (ASE - Academy of Economic Studies Bucharest, University of Bucharest), profile studies conducted by the National Institute of Tourism Development (INCDT), data bases with tourist accommodation structures, classified according to the legislation in force, as well as the legislation regarding the classification of $\mathrm{ABH}$, the specific legislation for the disadvantaged mountain area, the National Territory Arrangement Plan -section 8-Tourism and rural pensions websites were taken into consideration. 


\section{Research Results}

\section{Descriptive Statistics}

In order to propose several measures to be implemented for the development of the tourism area, especially of the mounting area, it is necessary to present a descriptive statistic of the data on which the analysis is conducted. Thus, in Romania, at the time of 01.02.2018, when the database was consulted, there were 799 boarding houses, distributed in 39 counties, including the 27 counties included in DMA (Table no.1).

Table no. 1 Distribution of agro-touristic boarding houses (ABH) in 2018

\begin{tabular}{|c|l|l|l|l|l|}
\hline No. & County & $\begin{array}{l}\text { No. of boarding } \\
\text { houses }\end{array}$ & No. & County & $\begin{array}{l}\text { No. of } \\
\text { boarding } \\
\text { houses }\end{array}$ \\
\hline 1. & ALBA & 39 & 21 & SĂLAJ & 24 \\
\hline 2. & ARAD & 10 & 22 & SATU MARE & 12 \\
\hline 3. & ARGES & 23 & 23 & SIBIU & 22 \\
\hline 4. & BACĂU & 6 & 24 & SUCEAVA & 101 \\
\hline 5. & BIHOR & 22 & 25 & TIMIȘ & 15 \\
\hline 6. & BISTRIȚA NĂSĂUD & 50 & 26. & VÂLCEA & 14 \\
\hline 7. & BRAȘOV & 58 & 27. & VRANCEA & 7 \\
\hline 8. & BUZĂU & 11 & & TOTAL DMA & $\mathbf{7 4 2}$ \\
\hline 9. & CARAȘ SEVERIN & 9 & 28. & BOTOȘANI & 5 \\
\hline 10. & CLUJ & 73 & 29. & CĂLĂRAȘI & 1 \\
\hline 11. & COVASNA & 13 & 30 & CONSTANTTA & 2 \\
\hline 12. & DÂMBOVIȚA & 7 & 31 & DOL & 3 \\
\hline 13. & GORJ & 24 & 32 & GALAȚI & 3 \\
\hline 14. & HARGHITA & 42 & 33 & GIURGIU & 1 \\
\hline 15. & HUNEDOARA & 30 & 34 & IAȘI & 11 \\
\hline 16. & MARAMUREȘ & 75 & 35 & ILFOV & 5 \\
\hline 17. & MEHEDINȚI & 7 & 36 & OLT & 2 \\
\hline 18. & MUREȘ & 16 & 37 & TELEORMAN & 2 \\
\hline 19. & NEAMȚ & 29 & 38 & TULCEA & 17 \\
\hline 20. & PRAHOVA & 3 & 39. & VASLUI & 5 \\
\hline & & & & GRAND TOTAL & $\mathbf{7 9 9}$ \\
\hline
\end{tabular}

Source: www.turism.gov.ro

From the total number of 799 boarding houses, 57 are located in counties that are not included in any disadvantaged mountain area and therefore, will not be included in the analysis of the study. The remaining 742 are located in the counties that are included in the disadvantaged mountain area. This does not necessarily mean that the boarding houses are located in the territorial units included in the disadvantaged mountain area. Most boarding houses are in Suceava County, respectively 101 units. The fewest, three units, are in Prahova county. 
INTERNATIONAL JOURNAL OF ACADEMIC RESEARCH IN BUSINESS AND SOCIAL SCIENCES

Vol. 9, No. 5, May, 2019, E-ISSN: 2222-6990 @ 2019 HRMARS

In terms of development regions, the most numerous are in Region 6, North West, respectively 256 units. The smallest number of boarding houses, excluding Region 8, Bucharest - Ilfov, is located in Region 2 South East, namely 18 units (Table no.2).

Table no. 2. Distribution of agro-touristic boarding houses by regions, in 2018

\begin{tabular}{|c|c|c|c|c|c|c|}
\hline Region & $\mathbf{1}^{*}$ & $\mathbf{2}^{*}$ & $\mathbf{3}^{*}$ & $\mathbf{4}^{*}$ & $\mathbf{5}^{*}$ & Total \\
\hline 1 North-East & $\mathbf{2}$ & 33 & 96 & 5 & 0 & 136 \\
\hline 2 South-East & 0 & 5 & 13 & 0 & 0 & 18 \\
\hline 3 South-Muntenia & 0 & 12 & 17 & 3 & 1 & 33 \\
\hline 4 South-West Oltenia & 2 & 10 & 30 & 3 & 0 & 45 \\
\hline 5 West & 0 & 23 & 40 & 1 & 0 & 64 \\
\hline 6 North-West & 6 & 125 & 115 & 9 & 1 & 256 \\
\hline 7 Center & 7 & 75 & 102 & 6 & 0 & 190 \\
\hline Total & 17 & 283 & 413 & 27 & 2 & $\mathbf{7 4 2}$ \\
\hline
\end{tabular}

Source: www.turism.gov.ro

Out of the 742 rural pensions located in counties included in the disadvantaged mountain area, 470 are in the territorial administrative units from disadvantaged mountain areas. 292 out of these are of high touristic potential, 134 with very high touristic potential and 44 are without touristic potential, but included in the disadvantaged mountain area. Unfortunately, in four of the 27 counties included in the disadvantaged mountain area there aren't any boarding houses in any territorial administrative unit. Dambovita, Salaj, Satu Mare, Timis.

\section{Measures Proposed Related To Several Areas of Tourist Development}

Based on the descriptive statistics presented in Table no. 1 and Table no. 2, a first possible conclusion is that an action plan for boarding houses development should only pursue the 470 boarding houses located in the territorial administrative units which are part of a disadvantaged mountain area. We believe that the study should be extended at least to the Carpathian Convention (CC), for those units who are not included in a disadvantaged mountain area.

Under these circumstances, we propose that the action plan should be designed on several areas. The first one should be related with tourism destination. This is linked with the action regarding the promotion of tourism potential as it is presented in "Sustainable Development Strategy of Romania, Orizonturi 2013-2020-2030 Horizons (Romanian Government, 2008)". 
INTERNATIONAL JOURNAL OF ACADEMIC RESEARCH IN BUSINESS AND SOCIAL SCIENCES

Vol. 9, No. 5, May, 2019, E-ISSN: 2222-6990 @ 2019 HRMARS

Table no. 3. Tourism destination's recommendations

\begin{tabular}{|c|c|c|c|c|}
\hline Subchapter & Action & Explanations & Deadline & Financial source \\
\hline $\begin{array}{l}\text { Documentation } \\
\text { / Research }\end{array}$ & $\begin{array}{l}\text { Touristic } \\
\text { villages }\end{array}$ & $\begin{array}{l}\text { Development of the } \\
\text { villages in the regions } \\
\text { with a high number of } \\
\text { boarding houses }\end{array}$ & TM & $\begin{array}{l}\text { Financing the } \\
\text { study regarding } \\
\text { specific criteria on } \\
\text { how to set up the } \\
\text { "tourist village", } \\
\text { public funds }\end{array}$ \\
\hline $\begin{array}{l}\text { Establishing } \\
\text { village } \\
\text { monographs }\end{array}$ & $\begin{array}{l}\text { Editing of the } \\
\text { monographs } \\
\text { for the } \\
\text { touristic } \\
\text { villages }\end{array}$ & $\begin{array}{l}\text { Promoting the villages in } \\
\text { order to attract more } \\
\text { market segments }\end{array}$ & LT & $\begin{array}{l}\text { Public / European } \\
\text { funds for } \\
\text { advertising }\end{array}$ \\
\hline $\begin{array}{l}\text { Ethnographic } \\
\text { destinations }\end{array}$ & $\begin{array}{l}\text { Overlapping } \\
\text { tourist } \\
\text { destinations } \\
\text { and } \\
\text { ethnographic } \\
\text { destinations } \\
\end{array}$ & $\begin{array}{l}\text { Research of the issue } \\
\text { collaborating with the } \\
\text { open air museum } \\
\text { network }\end{array}$ & MT & $\begin{array}{l}\text { Collaborating with } \\
\text { outdoor } \\
\text { museums. Does } \\
\text { not involve funds }\end{array}$ \\
\hline $\begin{array}{l}\text { Studies } \\
\text { regarding the } \\
\text { development } \\
\text { potential } \\
\text { related to the } \\
\text { growth of the } \\
\text { boarding } \\
\text { houses sector }\end{array}$ & $\begin{array}{l}\text { Studies on the } \\
\text { area where } \\
\text { new boarding } \\
\text { houses could } \\
\text { develop }\end{array}$ & $\begin{array}{l}\text { As a result of the } \\
\text { research, we found an } \\
\text { uneven development of } \\
\text { the boarding houses in } \\
\text { Romania. The current } \\
\text { stage of development is } \\
\text { below the potential that } \\
\text { could be associated with } \\
\text { the local gastronomy. }\end{array}$ & LT & $\begin{array}{l}\text { Public funds, } \\
\text { European funds }\end{array}$ \\
\hline $\begin{array}{l}\text { Eco museums } \\
\text { development }\end{array}$ & $\begin{array}{l}\text { Pointing on } \\
\text { areas which } \\
\text { could be } \\
\text { adapted or } \\
\text { converted to } \\
\text { eco museums }\end{array}$ & $\begin{array}{l}\text { It allows a better } \\
\text { advertising of the region } \\
\text { and also of the boarding } \\
\text { houses located in that } \\
\text { region (Sibiu) }\end{array}$ & MT & $\begin{array}{l}\text { Public funds, } \\
\text { European funds }\end{array}$ \\
\hline $\begin{array}{l}\text { Developing the } \\
\text { European } \\
\text { cultural routes }\end{array}$ & $\begin{array}{l}\text { Establishing } \\
\text { destinations } \\
\text { that present } \\
\text { monuments } \\
\text { that can be } \\
\text { included in the }\end{array}$ & $\begin{array}{lr}\text { Developing } & \text { destination } \\
\text { networks based on } \\
\text { European cultural routes } \\
\text { (including } \\
\text { products) }\end{array}$ & MT & Public funds \\
\hline
\end{tabular}


INTERNATIONAL JOURNAL OF ACADEMIC RESEARCH IN BUSINESS AND SOCIAL SCIENCES

Vol. 9, No. 5, May, 2019, E-ISSN: 2222-6990 @ 2019 HRMARS

\begin{tabular}{|c|c|c|c|c|}
\hline & $\begin{array}{l}\text { European } \\
\text { cultural routes }\end{array}$ & & & \\
\hline $\begin{array}{l}\text { Cultural parks } \\
\text { development }\end{array}$ & $\begin{array}{l}\text { Establishing } \\
\text { the areas with } \\
\text { hihh cultural } \\
\text { potential }\end{array}$ & $\begin{array}{l}\text { It allows a better } \\
\text { advertising of the } \\
\text { destination and, at the } \\
\text { same time, the } \\
\text { development of a new } \\
\text { concept in Romania. }\end{array}$ & LT & Public funds \\
\hline $\begin{array}{l}\text { Eco tourism } \\
\text { destination } \\
\text { development }\end{array}$ & $\begin{array}{l}\text { Establishing } \\
\text { the areas with } \\
\text { Eco touristic } \\
\text { potential }\end{array}$ & $\begin{array}{l}\text { Allows getting tourists } \\
\text { that are attracted to this } \\
\text { form of tourism, together, } \\
\text { with direct effect on } \\
\text { developing the specific } \\
\text { destination }\end{array}$ & MT & $\begin{array}{l}\text { Collaborating with } \\
\text { APL (Local Public } \\
\text { Authority) }\end{array}$ \\
\hline $\begin{array}{l}\text { Extending the } \\
\text { assistance on } \\
\text { the } \\
\text { agrotouristic } \\
\text { boarding } \\
\text { houses of the } \\
\text { Carpathian } \\
\text { Convention }\end{array}$ & $\begin{array}{l}\text { Study on the } \\
\text { agrotouristic } \\
\text { boarding } \\
\text { houses } \\
\text { located in the } \\
\text { administrative } \\
\text { units not } \\
\text { included in the } \\
\text { Disadvantaged } \\
\text { Mountain } \\
\text { Area but } \\
\text { included in the } \\
\text { CC }\end{array}$ & $\begin{array}{l}\text { The double delimitation } \\
\text { of the Carpathians, on } \\
\text { different criteria, led to } \\
\text { the non-inclusion of } \\
\text { territorial administrative } \\
\text { units in CC or } \\
\text { Disadvantaged Mountain } \\
\text { Area. For this reason, it } \\
\text { would be ideal to extend } \\
\text { the Agrotouristic } \\
\text { boarding houses to the } \\
\text { administrative units not } \\
\text { included in the u.a. not } \\
\text { included in the } \\
\text { Disadvantaged Mountain } \\
\text { Area but included in the } \\
\text { CC }\end{array}$ & ST & $\begin{array}{ll}\text { No } & \text { funds } \\
\text { necessary }\end{array}$ \\
\hline $\begin{array}{l}\text { Development } \\
\text { of the } \\
\text { statistical } \\
\text { system }\end{array}$ & $\begin{array}{l}\text { Establishing } \\
\text { exclusive } \\
\text { tourism } \\
\text { reports on the } \\
\text { destinations } \\
\text { included in the } \\
\text { Disadvantaged } \\
\text { Mountain }\end{array}$ & $\begin{array}{l}\text { In order to have a } \\
\text { complete picture of the } \\
\text { tourism development in } \\
\text { the administrative units } \\
\text { included in the } \\
\text { Disadvantaged Mountain } \\
\text { Area, a statistical analysis } \\
\text { should be carried out at }\end{array}$ & LT & $\begin{array}{l}\text { Depending on the } \\
\text { relationship with } \\
\text { NSI, }\end{array}$ \\
\hline
\end{tabular}




\begin{tabular}{|l|l|l|l|}
\hline $\begin{array}{l}\text { Area and } \\
\text { subsequently } \\
\text { in CC }\end{array}$ & $\begin{array}{l}\text { their level. It involves a } \\
\text { very active partnership } \\
\text { with NSI (National } \\
\text { Statistics Institute) }\end{array}$
\end{tabular} \mid

Source: own computation of the authors (own recommendations), where ST = short term, MT = middle term, $\mathrm{LT}=$ long term

Another area on which more attention should be focused on is the cultural heritage area. Thus, for further development of tourism, cultural heritage does not have to be neglected (Ciurea, 2011). The authors' recommendations on cultural heritage are found in Table no. 4.

Table no. 4. Cultural heritage recommendations

\begin{tabular}{|c|c|c|c|c|}
\hline Subchapter & Action & Explanations & Deadline & Financial source \\
\hline \multirow[t]{2}{*}{$\begin{array}{l}\text { Tangible } \\
\text { Cultural } \\
\text { Heritage }\end{array}$} & $\begin{array}{l}\text { Tangible Cultural } \\
\text { Heritage Audit }\end{array}$ & $\begin{array}{l}\text { It is necessary to carry } \\
\text { out an audit with } \\
\text { regard to P.C.M for } \\
\text { every tourist } \\
\text { destination where } \\
\text { there are ABH, at local } \\
\text { and regional level: } \\
\text { monument, type, } \\
\text { coordinates, web } \\
\text { pages, contact } \\
\text { persons }\end{array}$ & \begin{tabular}{l}
\multicolumn{2}{c}{ Depending } \\
on the \\
level: ST, \\
MT
\end{tabular} & $\begin{array}{l}\text { The legislation in } \\
\text { force through C.I.T. } \\
\text { (Romanian } \\
\text { abbreviation for } \\
\text { Touristic } \\
\text { Information Centre) } \\
\text { must be consulted. } \\
\text { The information } \\
\text { must be verified by } \\
\text { collaborating with } \\
\text { the, representatives } \\
\text { of the central public } \\
\text { authorities from } \\
\text { decentralized } \\
\text { institutions }\end{array}$ \\
\hline & $\begin{array}{l}\text { Protecting, } \\
\text { preserving and } \\
\text { promoting of } \\
\text { Tangible Cultural } \\
\text { Heritage }\end{array}$ & $\begin{array}{l}\text { In each tourist } \\
\text { destination PCM must } \\
\text { be protected, } \\
\text { preserved and } \\
\text { promoted to become } \\
\text { a source of attraction } \\
\text { for the consumer }\end{array}$ & LT & $\begin{array}{l}\text { European / national } \\
\text { funds to protect and } \\
\text { preserve PCMs } \\
\text { European / national } \\
\text { / private funds to } \\
\text { promote P.C.M. }\end{array}$ \\
\hline
\end{tabular}


INTERNATIONAL JOURNAL OF ACADEMIC RESEARCH IN BUSINESS AND SOCIAL SCIENCES Vol. 9, No. 5, May, 2019, E-ISSN: 2222-6990 @ 2019 HRMARS

\begin{tabular}{|c|c|c|c|c|}
\hline & $\begin{array}{l}\text { Traditional } \\
\text { architecture }\end{array}$ & $\begin{array}{l}\text { Preservation, } \\
\text { protection ond } \\
\text { promotion of } \\
\text { traditional } \\
\text { architecture: } \\
\text { - Development of } \\
\text { standard projects } \\
\text { with O.A.R (Romanian } \\
\text { language abbreviation } \\
\text { for Ordinul } \\
\text { Arhitectilor din } \\
\text { Romania - Convention } \\
\text { of Romanian } \\
\text { Architects) for } \\
\text { recognized } \\
\text { ethnographic regions } \\
\text { - Transforming } \\
\text { traditional old houses } \\
\text { into points of interest } \\
\text { - NOTE: For ABDs } \\
\text { located in buildings } \\
\text { that conserve cultural } \\
\text { heritage, It would be } \\
\text { recommended to } \\
\text { access } \\
\text { financing through } \\
\text { European funds. }\end{array}$ & LT & $\begin{array}{l}\text { Depending on the } \\
\text { type of action: no } \\
\text { funds / european / } \\
\text { national or private } \\
\text { funds }\end{array}$ \\
\hline $\begin{array}{l}\text { Investments } \\
\text { PCM } \\
\text { (Romanian } \\
\text { abbreviation } \\
\text { for Tangible } \\
\text { Cultural } \\
\text { Heritage) }\end{array}$ & $\begin{array}{l}\text { Conservation of } \\
\text { the buildings with } \\
\text { traditional } \\
\text { architecture }\end{array}$ & $\begin{array}{l}\text { The possible opening } \\
\text { of a } \mathrm{ABH} \text { in buildings } \\
\text { with traditional } \\
\text { architecture should } \\
\text { be } 100 \% \text { financed and } \\
\text { exempt from taxes }\end{array}$ & LT & $\begin{array}{l}\text { Public or private } \\
\text { funds }\end{array}$ \\
\hline \multirow{2}{*}{$\begin{array}{l}\text { Imaterial PCl } \\
\text { (Romanian } \\
\text { abbreviation } \\
\text { for Non- } \\
\text { tangible } \\
\text { Cultural } \\
\text { Heritage) }\end{array}$} & Audit $\mathrm{PCl}$ & $\begin{array}{l}\text { Establishing the main } \\
\text { ways of } \mathrm{PCl} \text { for every } \\
\text { destination }\end{array}$ & ST & $\begin{array}{l}\text { Databases in } \\
\text { collaboration with } \\
\text { the network of } \\
\text { outdoor museums }\end{array}$ \\
\hline & $\begin{array}{l}\text { Establishing a } \\
\text { connectioon } \\
\text { between tourism / }\end{array}$ & $\begin{array}{l}\text { Establishment and } \\
\text { evaluation } \\
\text { gastronomic heritage } \\
\text { in connection with }\end{array}$ & MT & Databases \\
\hline
\end{tabular}


INTERNATIONAL JOURNAL OF ACADEMIC RESEARCH IN BUSINESS AND SOCIAL SCIENCES

Vol. 9, No. 5, May, 2019, E-ISSN: 2222-6990 @ 2019 HRMARS

\begin{tabular}{|c|c|c|c|}
\hline $\begin{array}{l}\text { gastronomy and } \\
\text { local drinks }\end{array}$ & $\begin{array}{l}\text { tourism and tourist } \\
\text { destinations: } \\
\text { traditional products, } \\
\text { recipes }\end{array}$ & & \\
\hline $\begin{array}{l}\text { Establishing of } \\
\text { guides / } \\
\text { traditional recipes } \\
\text { for gourmet } \\
\text { products } \\
\text { traditional } \\
\text { beverages }\end{array}$ & $\begin{array}{l}\text { The development of } \\
\text { the guides has a } \\
\text { double objective: } \\
\text { keeping the } \\
\text { traditional recipes } \\
\text { indoor and also } \\
\text { promoting them }\end{array}$ & MT & $\begin{array}{l}\text { European / national } \\
\text { or private funds }\end{array}$ \\
\hline $\begin{array}{l}\text { Developing of a } \\
\text { local events } \\
\text { calendar }\end{array}$ & $\begin{array}{l}\text { Establishing the most } \\
\text { important traditional } \\
\text { events that preserve } \\
\text { the cultural heritage } \\
\text { and containing them } \\
\text { in the calendar }\end{array}$ & MT & $\begin{array}{l}\text { Databases of local } \\
\text { public authorities }\end{array}$ \\
\hline $\begin{array}{l}\text { Protect, preserve } \\
\text { and promote } \mathrm{PCl}\end{array}$ & $\begin{array}{l}\text { PCl must be preserved } \\
\text { and promoted in } \\
\text { every tourist } \\
\text { destination, including } \\
\text { craftsmen. Organizing } \\
\text { of courses/organizing } \\
\text { of training facilities, } \\
\text { funds allocation for } \\
\text { the selling point } \\
\text { development }\end{array}$ & MT & $\begin{array}{l}\text { Database. } \\
\text { Public funds on } \\
\text { tourist destinations. }\end{array}$ \\
\hline Event organisation & $\begin{array}{l}\text { Organizing } \\
\text { gastronomic events } \\
\text { with an impact on } \\
\text { attracting tourists to } \\
\text { certain dates }\end{array}$ & MT & $\begin{array}{l}\text { Public and private } \\
\text { funds }\end{array}$ \\
\hline $\begin{array}{l}\text { D.O.C (Romanian } \\
\text { language } \\
\text { abbreviation for } \\
\text { Denumire de } \\
\text { Origine Controlata } \\
-\quad \text { Controlled } \\
\text { designation of } \\
\text { origin) }\end{array}$ & $\begin{array}{l}\text { Development of D.O.C } \\
\text { products with direct } \\
\text { influence on the } \\
\text { realization of a local } \\
\text { gastronomic identity }\end{array}$ & MT & European funds \\
\hline
\end{tabular}


INTERNATIONAL JOURNAL OF ACADEMIC RESEARCH IN BUSINESS AND SOCIAL SCIENCES

Vol. 9, No. 5, May, 2019, E-ISSN: 2222-6990 @ 2019 HRMARS

\begin{tabular}{|c|c|c|c|c|}
\hline \multirow[t]{2}{*}{ Investments } & $\begin{array}{l}\text { Establishing selling } \\
\text { points for } \mathrm{PCl}- \\
\text { related products }\end{array}$ & $\begin{array}{l}\text { Selling points are } \\
\text { needed in order to } \\
\text { attract tourists. } \\
\text { Generally established } \\
\text { close to the CIT, } \\
\text { monuments (creating } \\
\text { the dual } \\
\text { consciousness, the } \\
\text { heritage } \\
\text { consciousness and the } \\
\text { event consciousness) }\end{array}$ & MT & $\begin{array}{l}\text { Public funds, } \\
\text { European funds }\end{array}$ \\
\hline & $\begin{array}{l}\text { Digitalising of the } \\
\text { heritage in the } \\
\text { mountain area }\end{array}$ & $\begin{array}{l}\text { A database regarding } \\
\text { the national heritage } \\
\text { in the DMA is } \\
\text { essential and can be } \\
\text { used not only to } \\
\text { promote the area but } \\
\text { also to promote and } \\
\text { help the ABH to } \\
\text { develop more } \\
\text { attractive websites }\end{array}$ & LT & $\begin{array}{l}\text { Partnership with } \\
\text { I.N.P. to create the } \\
\text { database }\end{array}$ \\
\hline
\end{tabular}

Source: own computation of the authors (own recommendations), where ST = short term, MT = middle term, $\mathrm{LT}=$ long term

The natural heritage is also important. In the "Sustainable Development Strategy of Romania, 20132020-2030 Horizons (Romanian Government, 2008)", the main objective is the improvement of natural resource management and the avoidance of exploiting them excessively, by recognizing the value of services provided by ecosystems, while the 2030 objective is significant approach of environmental performance to other EU Member States. Same objective can be observed in the "National Strategy for sustainable deelopment of Romania, 2030" as it aims for strengthening the protection efforts, regarding cultural and natural heritage and the landscape in rural and urban areas. 
INTERNATIONAL JOURNAL OF ACADEMIC RESEARCH IN BUSINESS AND SOCIAL SCIENCES

Vol. 9, No. 5, May, 2019, E-ISSN: 2222-6990 @ 2019 HRMARS

Table no. 5 Natural heritage recommendations

\begin{tabular}{|c|c|c|c|c|}
\hline Subchapter & Action & Explanations & Deadline & Financial source \\
\hline $\begin{array}{l}\text { Conservation, } \\
\text { protection } \\
\text { and } \\
\text { promotion of } \\
\text { natural } \\
\text { heritage }\end{array}$ & $\begin{array}{l}\text { Audit of the } \\
\text { natural protected } \\
\text { areas from the } \\
\text { places where } \\
\text { there are } \mathrm{ABH}\end{array}$ & $\begin{array}{l}\text { Natural protected areas } \\
\text { are a point of attraction. } \\
\text { The existence of a } \\
\text { manager of such an area } \\
\text { can lead to collaborating } \\
\text { with } \mathrm{ABH} \text { for new tourism } \\
\text { products development }\end{array}$ & $\mathrm{MT}$ & $\begin{array}{l}\text { Databases } \\
\text { containing the } \\
\text { natural protected } \\
\text { areas, their } \\
\text { administrators, } \\
\text { existing natural } \\
\text { and / or cultural } \\
\text { heritage }\end{array}$ \\
\hline $\begin{array}{l}\text { Alternative } \\
\text { energy } \\
\text { sources }\end{array}$ & $\begin{array}{l}\text { Carrying out } \\
\text { projects to provide } \\
\text { alternative energy } \\
\text { sources as well as } \\
\text { for the destination } \\
\text { as for the } \mathrm{ABH}\end{array}$ & $\begin{array}{l}\text { The use of alternative } \\
\text { energy sources is a great } \\
\text { advantage for the tourist } \\
\text { destination as well as for } \\
\text { the } A B H \text { in which they are } \\
\text { being used }\end{array}$ & LT & $\begin{array}{l}\text { European funds. } \\
\text { Ideally, there } \\
\text { should be public } \\
\text { funds to allow the } \\
\text { ongoing projects }\end{array}$ \\
\hline $\begin{array}{l}\text { Waste } \\
\text { management } \\
\text { systems }\end{array}$ & $\begin{array}{l}\text { Awareness raising } \\
\text { actions on how } \\
\text { waste is handled. } \\
\text { Waste recycling }\end{array}$ & $\begin{array}{l}\text { Using waste recycling } \\
\text { methods and waste } \\
\text { management awareness: } \\
\text { creates a positive impact } \\
\text { on the visitor and can also } \\
\text { be turned into an } \\
\text { advertising system }\end{array}$ & LT & $\begin{array}{l}\text { European funds } \\
\text { from } \\
\text { environmental } \\
\text { programs }\end{array}$ \\
\hline
\end{tabular}

Source: own computation of the authors (own recommendations), where ST = short term, MT = middle term, LT = long term

We also have to consider other areas that are linked with the tourism activity such as the system on which the tourism activity is organized and coordinated. Information related to tourism activities has to presented, easy to use and to access. In Romania, in 2017,May, $10^{\text {th }}$, the Ministry of Tourism (2017) launched the National Center for Sustainable Tourism, an instrument that belongs to the Carpathian Platform, which is an objective of the Carpathian Convention. Thus, in tourism sector the platform aims to create a map of tourist destination, national and international tourism institution and to facilitate their communication for implementing the Carpathian Convention Strategy. Our recommendations are presented in Table no. 6. 
INTERNATIONAL JOURNAL OF ACADEMIC RESEARCH IN BUSINESS AND SOCIAL SCIENCES Vol. 9, No. 5, May, 2019, E-ISSN: 2222-6990 @ 2019 HRMARS

Table no. 6. Developing the tourist destinations system of organizing and coordination

\begin{tabular}{|c|c|c|c|c|}
\hline Subchapter & Action & Explanations & Deadline & Financial source \\
\hline \multirow[t]{4}{*}{$\begin{array}{l}\text { C.I.T. } \\
\text { (Romanian } \\
\text { abbreviation } \\
\text { for Touristic } \\
\text { Information } \\
\text { Centre) }\end{array}$} & C.I.T. Audit & $\begin{array}{l}\text { Establishing the tourist } \\
\text { destinations with the } \\
\text { existence of C.I.T. on a local } \\
\text { or regional level (county, } \\
\text { ethnographic } \\
\text { mountainous) } \\
\text { national.level }\end{array}$ & ST & No funds needed \\
\hline & & $\begin{array}{l}\text { Database development with } \\
\text { C.I.T., location, address, } \\
\text { phone, e-mail, web page }\end{array}$ & ST & No funds needed \\
\hline & & $\begin{array}{l}\text { Development of the contact } \\
\text { database with the City Hall, } \\
\text { C.I.T., address, telephone, e- } \\
\text { mail }\end{array}$ & ST & No funds needed \\
\hline & $\begin{array}{l}\text { Collaborating } \\
\text { with C.I.T. }\end{array}$ & $\begin{array}{l}\text { Developing C.I.T network on } \\
\text { a local, regional and national } \\
\text { level in order to gather and } \\
\text { transmit information about } \\
\text { ABH }\end{array}$ & ST & $\begin{array}{l}\text { Funds needed for } \\
\text { spreading the } \\
\text { promotional } \\
\text { materials. }\end{array}$ \\
\hline \multirow[t]{2}{*}{ Associations } & Databases & $\begin{array}{l}\text { Database with all the existing } \\
\text { associations from the tourist } \\
\text { destination }\end{array}$ & ST & Databases \\
\hline & $\begin{array}{l}\text { Developing } \\
\text { of } \\
\text { associations }\end{array}$ & $\begin{array}{l}\text { The requirement of } \\
\text { organizing professional } \\
\text { associations to support and } \\
\text { to represent the sector on a } \\
\text { local, regional and national } \\
\text { level is necessary. These } \\
\text { associations might be } \\
\text { exclusively advertising } \\
\text { associations,advertising and } \\
\text { development associations } \\
\text { and in some cases, they } \\
\text { might become DMO ( } \\
\text { Destination Management } \\
\text { Organizations) }\end{array}$ & MT & $\begin{array}{l}\text { Financial funds for } \\
\text { legal registration } \\
\text { of the associations } \\
\text { and other } \\
\text { expenses. The } \\
\text { funds can be } \\
\text { obtained through } \\
\text { projects with } \\
\text { national and / or } \\
\text { international } \\
\text { funding }\end{array}$ \\
\hline
\end{tabular}




\begin{tabular}{|l|l|l|l|}
\hline $\begin{array}{l}\text { Development } \\
\text { of a booking } \\
\text { systems } \\
\text { (locally, } \\
\text { regional, } \\
\text { national) on } \\
\text { line and off } \\
\text { line }\end{array}$ & $\begin{array}{l}\text { They can develop locally, } \\
\text { regionally } \\
\text { ethnographic } \begin{array}{r}\text { LT area, } \\
\text { mountainous area) and at a } \\
\text { national level in order to } \\
\text { allow an easy consumer } \\
\text { access. }\end{array}\end{array}$ & $\begin{array}{l}\text { Funding of the web } \\
\text { site (portal) and of } \\
\text { the specialized } \\
\text { staff can be done } \\
\text { on European funds } \\
\text { or on own funds of } \\
\text { the operators who } \\
\text { develop the } \\
\text { program }\end{array}$ \\
\hline
\end{tabular}

Source: own computation of the authors (own recommendations), where ST = short term, MT = middle term, LT = long term

The marketing strategy is also important and should be conducted on available and reliable data. The recommendations on marketing instruments are presented in Table no. 7. 
INTERNATIONAL JOURNAL OF ACADEMIC RESEARCH IN BUSINESS AND SOCIAL SCIENCES

Vol. 9, No. 5, May, 2019, E-ISSN: 2222-6990 @ 2019 HRMARS

Table no. 7. Marketing recommendations

\begin{tabular}{|c|c|c|c|c|}
\hline Subchapter & Action & Explanations & $\begin{array}{l}\text { Deadlin } \\
\text { e }\end{array}$ & Financial source \\
\hline $\begin{array}{l}\text { Market } \\
\text { research }\end{array}$ & $\begin{array}{l}\text { Carring out } \\
\text { of a survey } \\
\text { related to } \\
\text { consumers / } \\
\text { tourists } \\
\text { arriving in } \\
\text { the } A B H\end{array}$ & $\begin{array}{l}\text { The research will allow the } \\
\text { establishment of the market } \\
\text { segments on a national, regional or } \\
\text { local level, that prefer the } \mathrm{ABH} \text {. By } \\
\text { default, it will indirectly allow the } \\
\text { establishment of the most } \\
\text { appropriate target market } \\
\text { segments }\end{array}$ & $\mathrm{MT}$ & $\begin{array}{l}\text { European funds, } \\
\text { private funds. } \\
\text { It is also possible } \\
\text { without funds by } \\
\text { submitting } \\
\text { questionnaire to be } \\
\text { followed by the } A B H\end{array}$ \\
\hline \multirow[t]{2}{*}{$\begin{array}{l}\text { Tourist } \\
\text { products }\end{array}$} & $\begin{array}{l}\text { Developing } \\
\text { regional } \\
\text { tourism } \\
\text { products }\end{array}$ & $\begin{array}{l}\text { Collaboration between the } \mathrm{ABH} \\
\text { can lead to the development of } \\
\text { regional tourism products with a } \\
\text { direct influence on the increase of } \\
\text { the average duration of the stay }\end{array}$ & MT & $\begin{array}{l}\text { It only involves } \\
\text { collaboration } \\
\text { between the } A B H\end{array}$ \\
\hline & $\begin{array}{l}\text { Establishmen } \\
\mathrm{t} \text { of the } \\
\text { tourism } \\
\text { products }\end{array}$ & $\begin{array}{l}\text { The generic "Holiday in (...name of } \\
\text { the olcation)", "Gastronomy and } \\
\text { tourism in (... name of the } \\
\text { location)" can attract tourists but, } \\
\text { at the same time, synthetize the } \\
\text { ABH's efforts towards thinking } \\
\text { about specific tourist products / } \\
\text { identity at ABH's level. The generic } \\
\text { coud also be: "Holiday in } \\
\text { Agrotouritic pensions" }\end{array}$ & MT & $\begin{array}{l}\text { It involves } \mathrm{ABH} \text { 's } \\
\text { effort, possibly } \\
\text { marketing } \\
\text { consulting. Private } \\
\text { funds, European } \\
\text { funds }\end{array}$ \\
\hline Distribution & $\begin{array}{l}\text { Distributing } \\
\text { of the } \\
\text { tourism } \\
\text { product from } \\
\text { the } A B H \text { to } \\
\text { the } \\
\text { consumer }\end{array}$ & $\begin{array}{l}\text { Obviously the generic "Travel to } \\
\text { ABH" product can also be } \\
\text { distributed in the current form: } \\
\text { web pages, tour operators, etc. } \\
\text { Clearly a centralized service with } \\
\text { subsidiaries is needed on regions } \\
\text { with the richest activity. } \\
\text { Normally this step will take place } \\
\text { after a very thorough research! } \\
\text { A first step could be to send the } \\
\text { ABH offers to interested tour } \\
\text { operators and CITs! The ABH } \\
\text { catalog or ABH's portal are } \\
\text { essential from this point of view }\end{array}$ & LT & $\begin{array}{l}\text { Private funds / } \\
\text { European funds for } \\
\text { the promotion } \\
\text { component }\end{array}$ \\
\hline
\end{tabular}

Source: own computation of the authors (own recommendations), where ST = short term, MT = middle term, $\mathrm{LT}=$ long term 
INTERNATIONAL JOURNAL OF ACADEMIC RESEARCH IN BUSINESS AND SOCIAL SCIENCES

Vol. 9, No. 5, May, 2019, E-ISSN: 2222-6990 ㄷ 2019 HRMARS

The marketing activity is also important as it could emphasize a better development of tourism activity, tourism services and tourism development in Romania. The author recommendations are presented in Table no. 8.

Table no. 8. Marketing / promotional mix

\begin{tabular}{|c|c|c|c|c|}
\hline \multirow[t]{3}{*}{$\begin{array}{l}\text { Advertiseme } \\
\text { nt }\end{array}$} & $\begin{array}{l}\text { Catalog } \\
\text { publishing }\end{array}$ & $\begin{array}{l}\text { Publishing of an annual catalog } \\
\text { containing information about the } \\
\mathrm{ABH} \text { from each destination in } \\
\text { Romania }\end{array}$ & MT & $\begin{array}{l}\text { European funds, } \\
\text { private funds }\end{array}$ \\
\hline & $\begin{array}{l}\text { Brochures } \\
\text { and leaflets }\end{array}$ & $\begin{array}{l}\text { Publishing of promotional materials } \\
\text { on counties (where appropriate), } \\
\text { ethnographic regions, and specific } \\
\text { areas including the } \mathrm{ABH}^{\prime} \text { 's in the } \\
\text { region and the presentation of the } \\
\text { natural and cultural heritage. } \\
\text { Depending on the edition, can be } \\
\text { published annually }\end{array}$ & MT & $\begin{array}{l}\text { Private funds, } \\
\text { European funds }\end{array}$ \\
\hline & $\begin{array}{l}\text { Radio } \\
\text { campaigns }\end{array}$ & $\begin{array}{l}\text { The national radio station has the } \\
\text { power to cover the entire territory } \\
\text { of Romania, especially the age } \\
\text { segments that should be targeted } \\
\text { for the } A B H^{\prime} \text { s }\end{array}$ & MT & $\begin{array}{l}\text { Private funds, } \\
\text { European funds }\end{array}$ \\
\hline \multirow[t]{3}{*}{$\begin{array}{l}\text { Sales } \\
\text { promotion }\end{array}$} & $\begin{array}{l}\text { Organizing / } \\
\text { participation } \\
\text { of fairs in } \\
\text { urban / rural } \\
\text { areas }\end{array}$ & $\begin{array}{l}\text { The } \mathrm{ABH} \text { offer must be promoted. } \\
\text { In this respect one of the most } \\
\text { recognized ways is the participation } \\
\text { at tourism / agricultural products } \\
\text { fairs in the country and abroad and } \\
\text { also organizing such fairs (Ex. } \\
\text { Suceava). Concretely, participation } \\
\text { at such a fair in Bucharest and } \\
\text { organizing of a small event is } \\
\text { mandatory }\end{array}$ & MT & $\begin{array}{l}\text { Private funds to ensure } \\
\text { participation }\end{array}$ \\
\hline & $\begin{array}{l}\text { Mass media } \\
\text { visits, tour } \\
\text { operators } \\
\text { visits }\end{array}$ & $\begin{array}{l}\text { Organized in areas with high } \mathrm{ABH} \\
\text { density, the two instruments allow } \\
\text { a good advertisement of the } \mathrm{ABH} \text { at } \\
\text { national level }\end{array}$ & MT & $\begin{array}{l}\text { Private funds, } \\
\text { European funds }\end{array}$ \\
\hline & Web page & $\begin{array}{l}\text { A web page containing information } \\
\text { regarding all } \mathrm{ABH}^{\prime} \mathrm{s} \text { and the } \\
\text { heritage. The research shows the } \\
\text { need to improve the use of this } \\
\text { marketing tool }\end{array}$ & MT & $\begin{array}{l}\text { Private funds, } \\
\text { European funds }\end{array}$ \\
\hline
\end{tabular}


INTERNATIONAL JOURNAL OF ACADEMIC RESEARCH IN BUSINESS AND SOCIAL SCIENCES

Vol. 9, No. 5, May, 2019, E-ISSN: 2222-6990 @ 2019 HRMARS

\begin{tabular}{|l|l|l|l|l|}
\hline & $\begin{array}{l}\text { Promotional } \\
\text { items }\end{array}$ & $\begin{array}{l}\text { Common gifts that shoud promote } \\
\text { the idea of spending a holiday in } \\
\text { such a ABH }\end{array}$ & $\begin{array}{l}\text { Private funds } \\
\text { European funds }\end{array}$ \\
\hline $\begin{array}{l}\text { Public } \\
\text { relations }\end{array}$ & $\begin{array}{l}\text { Events on } \\
\text { tourism and } \\
\text { gastronomy }\end{array}$ & $\begin{array}{l}\text { One of the most effective tools to } \\
\text { promote a destination, in } \\
\text { conjunction with local gastronomy } \\
\text { / customs }\end{array}$ & $\begin{array}{l}\text { MT } \\
\text { conferences }\end{array}$ & $\begin{array}{l}\text { Organizing regional press } \\
\text { conferences in order to promote } \\
\text { ABH's, the local gastronomy and } \\
\text { heritage }\end{array}$ \\
\hline
\end{tabular}

Source: own computation of the authors (own recommendations), where ST = short term, MT = middle term, $\mathrm{LT}=$ long term

The "National Strategy for sustainable development of Romania, 2030 looks at the fact that all students have to acquire their knowledge and skills to promote sustainable development as the Romanian education is at a lower level than the average found in the European Union. Based on this, the recommendation made by authors are presented in Table no. 9. 
INTERNATIONAL JOURNAL OF ACADEMIC RESEARCH IN BUSINESS AND SOCIAL SCIENCES

Vol. 9, No. 5, May, 2019, E-ISSN: 2222-6990 @ 2019 HRMARS

Table no. 9. Permanent education / training

\begin{tabular}{|c|c|c|c|c|}
\hline Subchapter & Action & Explanations & Deadline & $\begin{array}{l}\text { Financial } \\
\text { source }\end{array}$ \\
\hline $\begin{array}{l}\text { Local public } \\
\text { authorities. } \\
\text { Representatives } \\
\text { of local } \\
\text { communities }\end{array}$ & $\begin{array}{l}\text { Short-term } \\
\text { trainings }\end{array}$ & $\begin{array}{l}\text { It is necessary to promote the idea of } \\
\text { tourism development at the level of } \\
\text { the local public authorities as a } \\
\text { general factor of economic } \\
\text { development. } \\
\text { Likewise, promoting the idea that } \\
\text { natural and cultural heritage helps to } \\
\text { develop the community } \\
\text { Este necesară promovarea ideii de } \\
\text { conservare a mediului/gestionare a } \\
\text { deșeurilor }\end{array}$ & ST & $\begin{array}{l}\text { European } \\
\text { funds }\end{array}$ \\
\hline Tourism classes & $\begin{array}{l}\text { Introducing } \\
\text { classes / lessons } \\
\text { in schools and } \\
\text { high schools to } \\
\text { prepare the } \\
\text { necessary staff }\end{array}$ & $\begin{array}{l}\text { A research needs to be made to } \\
\text { identify the needs in tourism. Based } \\
\text { on the results, the best / effective } \\
\text { measures can be taken. }\end{array}$ & MT & Public funds \\
\hline $\mathrm{CIT}$ & $\begin{array}{l}\text { CIT Training } \\
\text { Courses }\end{array}$ & $\begin{array}{l}\text { 6-months duration courses allow } \\
\text { obtaining a diploma in accordance } \\
\text { with the law }\end{array}$ & MT & $\begin{array}{l}\text { Private / } \\
\text { public funds, } \\
\text { depending } \\
\text { on the } \\
\text { situation }\end{array}$ \\
\hline $\begin{array}{l}\mathrm{ABH} \\
\text { representatives }\end{array}$ & $\begin{array}{l}\text { Short-term } \\
\text { trainings, } \\
\text { depending on } \\
\text { the situation }\end{array}$ & $\begin{array}{l}\text { Trainings covering several areas: } \\
\text { tourism (depending on need), } \\
\text { natural and cultural heritage, quality } \\
\text { standards, foreign languages, } \\
\text { activity in } A B H\end{array}$ & MT & $\begin{array}{l}\text { European } \\
\text { funds }\end{array}$ \\
\hline $\begin{array}{l}\text { Experience } \\
\text { exchange }\end{array}$ & $\begin{array}{l}\text { Exchanges of } \\
\text { experience at } \\
\text { regional and } \\
\text { national level }\end{array}$ & $\begin{array}{l}\text { Promoting the experience exchange } \\
\text { on a regional / national level allows } \\
\text { solving some problems based on } \\
\text { good practice models and } \\
\text { establishing a multi-level } \\
\text { collaboration between the } \mathrm{ABH}^{\prime} \mathrm{s}\end{array}$ & MT & $\begin{array}{l}\text { Private } \\
\text { funds, } \\
\text { European } \\
\text { funds }\end{array}$ \\
\hline Working groups & $\begin{array}{l}\text { Organizing } \\
\text { working groups } \\
\text { on areas of } \\
\text { interest }\end{array}$ & $\begin{array}{l}\text { In order to support the owners of the } \\
\text { ABH's, working groups can be } \\
\text { organized by: legislation, marketing, } \\
\text { mass media relationships. Through } \\
\text { these groups, all ABH's owners can } \\
\text { easily find out information in their } \\
\text { areas of interest }\end{array}$ & MT & $\begin{array}{l}\text { No funds } \\
\text { needed }\end{array}$ \\
\hline
\end{tabular}


INTERNATIONAL JOURNAL OF ACADEMIC RESEARCH IN BUSINESS AND SOCIAL SCIENCES Vol. 9, No. 5, May, 2019, E-ISSN: 2222-6990 @ 2019 HRMARS

\begin{tabular}{|l|l|l|l|l|}
\hline $\begin{array}{l}\text { Constantly } \\
\text { learning }\end{array}$ & $\begin{array}{l}\text { Free E-learning } \\
\text { platform }\end{array}$ & $\begin{array}{l}\text { Developing of a permanent training } \\
\text { system for the owners of the ABH's } \\
\text { in the mountain area }\end{array}$ & $\begin{array}{l}\text { MT } \\
\text { funds }\end{array}$ \\
\hline
\end{tabular}

Source: own computation of the authors (own recommendations), where ST = short term, $\mathrm{MT}=$ middle term, $L T=$ long term

According to "National Strategy for sustainable development of Romania, 2030" product registration in the national and international European standard quality system is a source though which value added is added to tourism sector, especially to rural development, based on their geographically origin. Thus, the quality systems emphasize the need of production both the quality goods and to ensure the safety for consumers. The authors recommendations are revealed in Table no. 10.

Table no. 10. Quality recommendations

\begin{tabular}{|l|l|l|l|}
\hline $\begin{array}{l}\text { Introducing quality standards } \\
\text { internationally recognized quality } \\
\text { standards (ISO) to establish a positive } \\
\text { image on the ABH level }\end{array}$ & $\begin{array}{l}\text { It is recommended to introduce } \\
\text { Establishing of } \\
\text { quality criteria at } \\
\text { ABH level }\end{array}$ & $\begin{array}{l}\text { In several European countries there is a } \\
\text { voluntary quality standard such as } \\
\text { "tourism in ABH". }\end{array}$ & $\begin{array}{l}\text { Public funds, European } \\
\text { funds }\end{array}$ \\
\hline $\begin{array}{l}\text { Establishing } \\
\text { specific icons / } \\
\text { labels for the } \\
\text { tourist offer in } \\
\text { the ABH }\end{array}$ & $\begin{array}{l}\text { Depending on the gourmet product } \\
\text { (food, drinks,etc.), pictograms can be } \\
\text { established in such a manner to be } \\
\text { easier identified }\end{array}$ & $\begin{array}{l}\text { Public funds, European } \\
\text { funds }\end{array}$ \\
\hline
\end{tabular}

Source: own computation of the authors (own recommendations), where ST = short term, $\mathrm{MT}=$ middle term, $\mathrm{LT}=$ long term

\section{Conclusions}

The analysis on the number and geographical distribution of the rural pensions gives a surprising picture in 2018, from the following points of view:

a) Reduced number of boarding houses at a national level

b) Reduced boarding houses number in territorial administrative units included in the disadvantaged mountain area

c) Lack of "traditional" counties by the number of rural pensions, among the counties with rural pensions in disadvantaged mountain area (Dâmboviţa, Satu Mare etc)

Taking into consideration these findings, the research carried out, but also the strategic objective established, the increase / development of the number of rural pensions at a national level (thus understanding the increase of the rural pensions number with $5 \%$ annually, for five years) we consider a unitary action plan for the less developed mentioned areas, by promoting successful examples such as Cluj, Braşov, Maramureş, would be useful if applied at a regional level. 
The research looked at the development of tourism activity in Romania and tries to provide several recommendation considering the regulation that is implemented. The recommendation look at some areas, such as Tourism destination, Cultural heritage, Natural heritage, Developing the tourist destinations system of organizing and coordination, Marketing and promotion mix, permanent education and quality criteria.

The problem of the research is linked with the fact that the proposals are recommendations conducted by the authors as the data is not totally available to the users.

One of the conclusions is also related to a strategic decision: action plans need to be developed for counties with a significant number of rural pensions, for example, over 20 rural pensions, in order to justify the planning efforts. Of course, at a later stage, all counties that have territorial administrative units included in the disadvantaged mountain area could be included.

Another conclusion is related to the need of a strategic decision: action plans should be developed exclusively for counties including administrative units included in the disadvantaged mountain area or, in order not to exclude certain counties, regional thinking systems may be developed, focusing on counties that have rural pensions in the administrative units located in disadvantaged mountain area. From the total of 470 rural pensions, most of them are located in Suceava (74) Cluj (58), Braşov (57) and Maramureş (45). Besides these, with a higher number of rural pensions, are the counties Harghita (38), Bistria- Nasaud (34) and Neamt (21). The fewest are in Arad, Bacau, Prahova, Vrancea (two) and Valcea (one).

Further research could take into consideration the degree in which the recommendations were implemented, the changes that should be done and the reasons why this (both changes and recommendations) were/ were not fulfilled.

We believe that an integrated development plan that highlights the destination and, at the same time, the boarding houses, is important. Otherwise, it is obvious that the boarding houses in Romania will only be able to develop by chance and isolated. For this reason, the action plan will present actions that appear to be not directly related to the development of the rural pensions themselves, but which will conduct to the development of the entire area and thus to the development of the agro touristic boarding houses.

\section{References}

Stancioiu, A. F. (2004), Strategii de marketing in turism, Bucuresti, Editura Economica Ion Valeriu Ciurea, 2011, Strategii De Dezvoltare Rurală

O. M. T. Studies, (1997), Rural Tourism, A solution for Employment, Local Development and Environment

Romanian Government The Ministry of Environment and Sustainable Development, (2008), United Nations Development Program National Center for Sustainable Development National Strategy for Sustainable Development Romania Horizons 2013-2020-2030,

The National Tourism Master Plan, (2007-2026), Romanian Government The Ministry of Regional Development and Tourism 